\title{
Benign Floor of the Mouth Neoplasm
}

National Cancer Institute

\section{Source}

National Cancer Institute. Benign Floor of the Mouth Neoplasm. NCI Thesaurus. Code C3593.

A non-metastasizing neoplasm that arises from the floor of the mouth. 